\title{
PETROLOGY AND THERMOBAROMETRY OF MANTLE XENOLITHS FROM THE EOCENE HOMESTEAD KIMBERLITE PIPE, CENTRAL MONTANA, USA
}

\author{
Anthony Irving ${ }^{1}$, Scott Kuehner ${ }^{1}$ and Peter Ellsworth ${ }^{2}$ \\ ${ }^{1}$ University of Washington, USA; ${ }^{2}$ Missoula, USA
}

\section{INTRODUCTION}

Eocene hypabyssal intrusions in the Grassrange region of central Montana comprise a variety of alkalic magma types including aillikite, alnöite, olivine monchiquite and kimberlite. The Homestead and Three Buttes bodies are true kimberlites based on criteria proposed by Mitchell (1995). These rocks consist mainly of variably altered olivine macrocysts in a matrix of phlogopite (with barian, kinoshitalite-rich cores), monticellite (at Homestead only), serpentine, calcite, apatite and chromite rimmed by titanomagnetite (some with atoll texture). Perovskite is present at Homestead, but the Three Buttes rock contains a $\mathrm{Ca}-\mathrm{Zr}-\mathrm{Nb}$ titanate mineral (probably zirkelite). Two other Grassrange intrusions at Yellow Water Butte and Elk Creek Butte, previously called lamproites by Mitchell and Bergman (1991), do not have mineralogic or chemical attributes of lamproitic rocks, and are instead aillikites.

\section{XENOLITH PETROLOGY}

Abundant garnet- and spinel-bearing mantle xenoliths occur in the Homestead pipe, and their size (up to 0.6 $\mathrm{m}$ ), density and relative freshness imply a very rapid rate of ascent and emplacement of this kimberlite magma. The xenolith lithologies are dominated by garnet lherzolites, with subordinate garnet harzburgites, spinel harzburgites, websterite and dunites. The websterite occurs as a $6 \mathrm{~mm}$ wide vein cutting a spinel harzburgite xenolith, and a narrow vein of clinopyroxenite is present in one garnet lherzolite xenolith; these veins probably represent igneous precipitates from mantle-derived magmas. Several peridotite xenoliths contain sparse patches of phlogopite mica and apatite, which probably represent additions from the host kimberlite. Large, angular grains of Cr-rich clinopyroxene in some samples of garnet lherzolite, harzburgite and dunite appear to be texturally unequilibrated. These clinopyroxenes may have formed by metasomatic reaction with alkalic or carbonatitic melts before or during xenolith ascent (as suggested also by Sr-Nd-Hf isotopic data for the Homestead peridotites - Carlson et al., 2003). The dunites are composed of mosaics of relatively large
Mg-rich olivine grains $\left(\mathrm{Fo}_{92.5}\right)$ with sparse chromite and minor interstitial phlogopitic mica, and resemble dunites accompanying garnet peridotites from the Williams kimberlites, north-central Montana.

\section{MINERAL COMPOSITIONS}

Garnets from polycrystalline xenoliths and loose garnet xenocrysts from the outcrop are predominantly $\mathrm{Cr}$ pyropes of G9 composition, although garnets in a few xenoliths plot in the G10 compositional field. Although the garnets are not particularly chromium-rich (maximum 6.2 wt.\% $\quad \mathrm{Cr}_{2} \mathrm{O}_{3}$ ), they are similar in composition to those from some diamondiferous kimberlites (including Kelsey Lake and Jericho) and from other Eocene Montana intrusions (such as the Williams kimberlites and the Macdougal Springs and Froze-to-Death Butte aillikites). Chromite compositions closely approach those from inclusions within diamond and from peridotite xenoliths associated with diamondiferous kimberlites. Estimated temperatures and pressures of equilibration for the garnet lherzolites fall in the range $1150-1200^{\circ} \mathrm{C}$ and 28 40 kilobars (equivalent to depths of 85-120 kilometers in the lithospheric mantle root of the Wyoming Craton). The websterite vein also gives an equilibration temperature of $1150^{\circ} \mathrm{C}$. These physical conditions are too hot or too shallow to fall within the stability field of diamond, and in fact lie on an unusually "hot" geotherm equivalent to a conductive heat flow of $\sim 60 \mathrm{~mW} / \mathrm{m}^{2}$

\section{REFERENCES}

Carlson, R. W., Irving, A. J., Schulze, D. J. and Hearn, B. C., Jr., 2003. Timing of lithospheric mantle modification beneath the Wyoming Craton. 8IKC Abstracts.

Mitchell, R. H., 1995. Kimberlites, Orangeites, and Related Rocks. Plenum, New York.

Mitchell, R. H. and Bergman, S. C., 1991. Petrology of Lamproites. Plenum, New York.

Contact: AJ Irving, Dept. of Earth and Space Sciences, Box

351310, University of Washington, Seattle, WA 98195,

USA, E-mail: irving@ess.washington.edu 